\title{
Preparation of 3D Au NPs-poly-L-glutamate/graphene Nanocomposite Modified Electrode for Sensing of Bisphenol A
}

\author{
Yuli Weil, ${ }^{1,2}$ Huihui An ${ }^{1}$, Wu Yang ${ }^{1, *}$, Hao Guo ${ }^{1}$ \\ ${ }^{1}$ College of Chemistry and Chemical Engineering, Key Lab of Bioelectrochemistry and \\ Environmental Analysis of Gansu Province, Northwest Normal University, Lanzhou 730070, China \\ ${ }^{2}$ Lanzhou Petrochemical Research Center, Petrochemical Research Institute, PetroChina, Lanzhou \\ 730060, P. R. China \\ *E-mail: xbsfda123@126.com
}

doi: $10.20964 / 2017.12 .24$

Received: 3 March 2017 / Accepted: 29 June 2017 / Published: 12 November 2017

\begin{abstract}
In this work, a simple, sensitive and rapid electrochemical sensor for bisphenol A determination based on a 3D Au NPs-poly-L-glutamate/graphene nanocomposite was proposed and the structures of the nanocomposite were characterized by scanning electron microscopy (SEM), Fourier transform infrared spectroscopic (FTIR) and X-ray diffraction (XRD). The electrochemical behaviors of bisphenol A on the nanocomposite GCE were investigated by cyclic voltammetry (CV) and differential pulse voltammetry (DPV). In the potential range of $0.0 \sim 1.0 \mathrm{~V}$, an irreversible oxidation peak appeared on the modified electrode in $0.1 \mathrm{~mol} \mathrm{~L}^{-1}$ phosphate buffer solution $(\mathrm{pH}=6.0)$. Under the optimum conditions, the anode peak current of bisphenol A increased linearly with the its concentration in the ranges from $0.009 \mu \mathrm{mol} \mathrm{L}^{-1}$ to $0.1 \mu \mathrm{mol} \mathrm{L}{ }^{-1}$ and $0.1 \mu \mathrm{mol} \mathrm{L}^{-1}$ to $1.0 \mu \mathrm{mol} \mathrm{L}^{-1}$ with the detection limit down to $3 \times 10^{-10} \mathrm{~mol} \mathrm{~L}^{-1}(\mathrm{~S} / \mathrm{N}=3)$ and the corresponding linear regression equations were $\operatorname{Ip} a(\mu \mathrm{A})=$ $-0.1129 C\left(\mu \mathrm{mol} \mathrm{L} \mathrm{L}^{-1}\right)+0.5532\left(\mathrm{~N}=6, \mathrm{R}^{2}=0.9057\right)$ and $\operatorname{Ipa}(\mu \mathrm{A})=-0.05970 C\left(\mu \mathrm{mol} \mathrm{L} \mathrm{L}^{-1}\right)+$ $0.02182\left(\mathrm{~N}=5, \mathrm{R}^{2}=0.9950\right)$ respectively. The proposed method was successfully used for the determination of bisphenol A content in wastewater and milk samples, and the recoveries were in the range from $98.10 \%$ to $104.9 \%$.
\end{abstract}

Keywords: bisphenol A, electrochemistry, grapheme, L-glutamic acid, sensors

\section{$\underline{\text { FULL TEXT }}$}

(C) 2017 The Authors. Published by ESG (www.electrochemsci.org). This article is an open access article distributed under the terms and conditions of the Creative Commons Attribution license (http://creativecommons.org/licenses/by/4.0/). 